\title{
The Use of ICT For Poverty Alleviation In Gubugklakah Village, Malang Regency
}

\author{
Penggunaan ICT Untuk Pengentasan Kemiskinan Di Desa \\ Gubugklakah, Kabupaten Malang
}

\author{
Rachmad Gustomy ${ }^{1}$, Ratnaningsih Damayanti ${ }^{2}$, Rizqi Bachtiar ${ }^{3}$ \\ ${ }^{1-3}$ Dept. of Governmental Science, Brawijaya University, Indonesia \\ Corresponding Email: rizqi.bachtiar@ub.ac.id
}

\begin{abstract}
Information and Communications Technology (ICT) has become one of the influential instruments for poverty alleviation. The argument is based on the fact that currently technology has played an important role in relation to the lives of many people. There are several projects conducted by the government in Indonesia utilising ICT to reduce poverty rate, such as establishing telecenter in some remote areas. This paper aims to identify the extent and the impact of the ICT convergence process that is carried out as an effort to improve the welfare of the community, specifically at Gubugklakah village, Malang Regency. The village is chosen as the locus of the research because the area, which is relatively far from the city center, received telecentre procurement assistance by the central government. By using descriptive qualitative methods, this study finds that ICT has not been converged to the maximum and the impact is less than optimal. Internet connection is only limited to middle and upper economic groups. The use of the worldwide-web at the village has also experienced ups and downs. For example, there is an improvement in the utilisation of techonolgy in education, tourism and government sectors which impact on a more effective work culture. People also usually surf the internet to search and watch educational, entertainment or trading content. However, the connection has a slow network connection which is problematic when many people use it. Furthermore, there is a need for educating people as well as incremental approach so that the internet can be in line with local culture.
\end{abstract}

Keywords: ICT, Malang, Poverty

\begin{abstract}
Abstrak
Teknologi Informasi dan Komunikasi (TIK) telah menjadi salah satu instrumen yang berpengaruh dalam pengentasan kemiskinan. Argumen tersebut didasarkan pada kenyataan bahwa saat ini teknologi telah memainkan peran penting dalam kaitannya dengan kehidupan banyak orang. Ada beberapa proyek yang dilakukan pemerintah di Indonesia yang memanfaatkan TIK untuk mengurangi angka kemiskinan, seperti membangun telecenter di beberapa daerah terpencil. Tulisan ini bertujuan untuk mengetahui sejauh mana dan dampak dari proses konvergensi TIK yang dilakukan sebagai upaya peningkatan kesejahteraan masyarakat khususnya di Desa Gubugklakah Kabupaten Malang. Desa ini dipilih sebagai lokus penelitian karena wilayah yang relatif jauh dari pusat kota mendapat bantuan pengadaan telecentre oleh pemerintah pusat. Dengan menggunakan metode deskriptif kualitatif, penelitian ini menemukan bahwa TIK
\end{abstract}




\section{Gustomy, Damayanti, Bachtiar: "The Use of ICT For Poverty Alleviation In Gubugklakah Village, Malang Regency"}

belum terkonvergensi secara maksimal dan dampaknya kurang optimal. Koneksi internet hanya terbatas pada kelompok ekonomi menengah ke atas. Penggunaan world wide web di desa juga mengalami pasang surut. Misalnya, peningkatan pemanfaatan teknologi di bidang pendidikan, pariwisata dan pemerintahan yang berdampak pada budaya kerja yang lebih efektif. Orang juga biasanya menjelajahi internet untuk mencari dan menonton konten pendidikan, hiburan, atau perdagangan. Namun, koneksi tersebut memiliki koneksi jaringan yang lambat yang menjadi masalah ketika banyak orang yang menggunakannya. Selain itu, perlu adanya edukasi kepada masyarakat serta pendekatan incremental agar internet dapat sejalan dengan budaya lokal.

Kata Kunci: TIK, Malang, Kemiskinan

\section{Background}

Information and Communications Technology (hereinafter ICT) has been widely used in almost all fields. Many sectors using ICT are generally triggered by vast development of the ICT, having significant influence on the livelihood of people. Chapman and Slaymaker (2002) call it 'digital revolution' that leads to information society

In the scope of government, for example, several policies are made by utilising the ICT to widen access to public services through e-government. Surabaya is the city in Indonesia that already implements e-government. Begun in 2002, the utilisation of ICT in the government of Surabaya has brought along some policies such as those concerning e-procurement, e-budgeting, e-Human Resource, e-monitoring, e-education, and some other ICT-based policies (Public Relations Surabaya, 2018). The utilisation of ICT is intended to improve public services and governance. Therefore, the involvement of ICT is inevitable along with the growing technology these days.

Based on the United Nations Development Programs (UNDP, 2001), the use of ICT in the development has played an essential role since such a technology is useful to provide what is needed in development process. Thus, in terms of the implementation in Indonesia, several policies and regulations have been (being) made and in place in order to give an opportunity to use ICT in all domains. For example, Law Number 14 of 2008 concerning Openness of Public Information, Law Number 25 of 2009 concerning Public Services, and some other technical policies such as open government, Satu Data, Satu Peta, and some more others are to prove that the use of ICT in governmental domain is essential to help improve public services.

To alleviate poverty, ICT serves as an important instrument to settle social issues. UNDP (2014), Bappenas (n.d.) (National Development Planning of Indonesia) emphasise that ICT is one of instruments implemented to alleviate poverty. Moreover, the use of ICT in developing countries is expected to give ease like never before to help alleviate 
poverty, improve basic health service and education. With it, it is expected that countries that are capable of placing potential basis of the ICT will be more prepared to face rapid economic growth, to significantly improve prosperity for a more democratic government (Cecchini and Scott, 2003).

A common example of the role of ICT as an instrument effective to improve people's prosperity is by stimulating the development of Micro, Small and Medium Enterprises (MSME). The involvement of ICT will enable the business actors of MSME to gain capital in easier way. Technically, this can be given by extending communication networks with finance providers, improving human resources, and establishing community networks for more extensive market.

Despite its important role in the process of settling disputes in society, the investment of ICT is not always welcomed in terms of the way it helps tackle poverty problem. Kim (2014) identifies two groups seeing the urgency of the role of ICT in poverty alleviation in the society, one of which is in favour of the idea that investment in ICT will help alleviate poverty and this group even believes that it will also improve economic development and other aspects such as political inclusiveness, freedom to speak, and gender equality.

The other group, however, is sceptical about the prospect of the investment in ICT. Tambo (2003) sees that such investment is wrongly addressed and costly. This doubt is strengthened by viewpoint believing that the best program of poverty alleviation should be directly addressed to people. However, the sceptical group cannot challenge the idea that the ICT development is inevitable and it is seen moving forward alongside the changing time. It proves that ICT convergence is entirely inevitable in all walks of life.

These two perspectives attract people to observe further through case studies. This is expected to contribute to the science regarding ICT intended to alleviate poverty. Furthermore, this perspective gives profound reflection regarding appropriateness between ICT convergence and social, cultural, and political conditions that blend together forming the characteristics of the people. The challenge to face not only involves that affecting the quality of human resources that are not capable of adapting to development of ICT in globalisation era, but it also takes into account the strategies of convergence and approaches suitable for the characters of the society.

The asymmetry of the strategy of ICT convergence to the social condition of the society does not certainly influence the fruitfulness of the program that requires the role of ICT. Survey involving the users and internet providers in several developing countries (Kenny, 2003) suggests that limited internet content that is local based and is provided in local language has served as the biggest barrier in the convergence of ICT in rural areas. 


\section{Gustomy, Damayanti, Bachtiar: "The Use of ICT For Poverty Alleviation In Gubugklakah Village, Malang Regency"}

Thus, attention given to all factors that have influence on people's life, either in micro or macro, internally or externally, has to be studied.

In such a case, researchers intends to seek into the influence by conducting a case study taking place in Gubugklakah, District of Poncokusumo, Regency of Malang. One case that is studied is telecenter program initiated by the government through the Ministry of Information and Communication in 2010.

This Telecenter will be discussed in tis research as part of process of ICT convergence in gubuk Klakah village recalling that it marked the initial access to the Internet in rural areas. Generally, Telecenter is a room where people of far distance can access information and technology to help them learn things and improve their knowledge of ICT. This is aimed to improve the welfare of the people in the rural areas (Ministry of Communication and Informatics, Regency of Malang, 2018). In the Regency of Malang, Telecenter project was initiated in four villages involving Gubug Klakah, Sukoanyar, Ampelgading, and Talangagung village, where this project is expected to help alleviate poverty in rural areas by increasing human and social capital.

\section{Sustainable Livelihoods Approach Through ICT In Poverty Alleviation}

In general, sustainable livelihoods approach in poverty alleviation is characterised by coordination and collaboration of sectors including policy makers (government and donors) and rule followers (poor people), with the hope that the poor will have their own assets, options, or strategies to live a better life (Chapman, 2003). In line with this definition, Soriano (2007) argues that this approach is intended to raise assets and improve human resources and to optimise the potential in rural areas where mortality rate is controlled.

In terms of the use of ICT, the ICT is used as a main assisting tool to run indicators of this approach. Therefore, there are at least two significances that can be achieved with this approach. Firstly, people will be well informed about the use of technology, information, and communication. With this, people should be more developed. Secondly, ICT is intended to make local governments more independent in making proper policies to help alleviate poverty with the hope that issues on poverty can be put to an end.

The above approach looks like the concept of smart city where the main indicator is in the society that is well informed and well developed with the use of ICT and with appropriately addressed public policy also involving ICT (Kitchin, 2013). Thus, similar condition can also take place in smaller and more specific regions such as villages. Villages managing to bring knowledge to their people under appropriately addressed policy of village government by involving ICT can also be labelled as 'smart village'. 
Therefore, the essence is that sustainable livelihoods approach can be performed by re-managing/offering assets owned by villages and their people. Generally, there are five assets/capitals in the context of ICT affecting the poverty alleviation program (Chapman, 2003):

a. Human capital involves improvement of access to education and training program through distance learning, improvement of varied facilities and infrastructure required in learning process, availability of access to digital content in rural areas with ease (in the form of text, picture, video, and radio) supported by large saving space on PC, ICT convergence with local culture.

b. Natural capital involves enhancement of resource management, use of ICT in information sharing and communication related to human resource management.

c. Financial capital involves support for financial management in rural areas through ICT, transparency of expenses in rural areas based on ICT.

d. Social capital involves development of rural community networks that are capable of spreading benefits including financial ones for rural people.

e. Physical capital involves expansion of rural commodity by utilising ICT, improvement of productivity capacity, management, and marketing of rural commodity by utilising ICT.

Each asset/capital mentioned above has every indicator that can be proposed for poverty alleviation through sustainable livelihoods approach by utilising ITC, where all the indicators can serve as a framework used to analyse the influence of ICT for poverty alleviation.

This research employed sustainable livelihoods approach within the context of ICT in poverty alleviation in Gubuglakah. Each indicator functions as a framework to find out the extent of influence of ICT on poverty alleviation where assets/capital are more focused regarding the process of the implementation of poverty alleviation program. Moreover, all those indicators can also see contributing and impeding factors of the ICTbased program of poverty alleviation.

\section{Research Method}

This is a qualitative-descriptive research where written materials, spoken words, cues, experiences, and behaviours were observed and taken as data (Suyanto and Sutinah; 2010). Primary data was obtained through purposive sampling to obtain correct and comprehensive information, while governmental materials like Central Bureau of Statistics (BPS) and mass media were taken as secondary data. 


\section{Gustomy, Damayanti, Bachtiar: "The Use of ICT For Poverty Alleviation In Gubugklakah Village, Malang Regency"}

\section{Rise And Fall Of ICT In Gubugklakah Village}

Telecenter was founded by Ministry of Communication and Informatics on 10 October 2010. Since then, Internet access has been introduced to villages. There seemed to be political intention regarding this establishment. The Internet access for villages was initiated by young people in villages through the name of a candidate for village head in order to realise the program. This way, what was expected was achieved, where the Internet access started to be perceived by village people and its operation was under the control of the ruling village head, and it has brought to what is known as Telecenter. Back in 2014 another election of a new village head was held, meaning that the aspiration of the youth shifted to another prospective candidate, and seemed to intimidate the ruling village head. Following this issue, the existing Internet access was disconnected by the village government but the inventory was still owned by the Telecenter. Seeing this change, the youth looked for a private provider that was capable of reaching Gubuk Klakah. Following the existence of Telecenter, the need of the locals for information technology extended to some other regions of Gubuk Klakah and the group of youth lent their hand to install Wi-Fi for both personal and public use.

Telecenter was initially funded by local government for its Internet network. Following the political conflict as mentioned above, the Internet used private funding from the locals under the name Lembaga Desa Wisata (an organisation under which rural tourism was organised) or commonly abbreviated as LADESTA. Telecenter received aid from PT. Bentoel in the form of computer sets to help with operational activities and facilities. However, the computers given were not in good condition with limited specs. Wi-Fi spots were mostly funded by institutions, village government, or individuals. At school area, the Wi-Fi was funded by schools, while local people have their own responsibility to fund their own wireless internet access.

The changing pattern of funding for Telecenter certainly changed the function of the telecenter per se, where the initial intention was to give empowerment and training for the locals. When money was earned, it would be transferred to the government of regency. Since the aid was stopped, Telecenter survived because it started to be commercialised. Telecenter earned money by charging Internet users as much as IDR 2000 every two hours. Telecenter also serves as a basecamp for LADESTA whose income came from tourism. Apart from its commercialisation, Telecenter has helped develop Internet access in the village since it was the only Internet centre in Gubuk Klakah.

All wireless Internet networks in Gubuk Klakah are based on local provider called Depth Wireless in Tumpang, while Internet access on smartphone still sticks to national provider such as Telkomsel and XL. Although the Telecenter has sifted to the secretariat 
of LADESTA, its change does not affect the function of Telecenter itself. Wireless Internet installation in Gubuk Klakah was helped by Telecenter but the operation was of the responsibility of each party. Similar to funding, Internet was funded by the organisation organising the service.

Telecenter in Gubuk Klakah was aimed to provide facilities and training concerning ICT for the village community. There are about 5 PCs that can be used as wireless Internet access in Telecenter where students ranging from primary level to high school often visit the center. The primary objective of the Telecenter is to give ICT facilities to the local community of Gubuk Klakah, but in reality the centre only provides a space without any regular training.

Telecenter is open to whoever needs Internet access or PC, where the operation of the Internet can be done independently by the users, or it can be guided by available Telecenter helpers. The guide given usually involves introduction to computer, printing, and holiday package for both businesses and people. Primary school children are specially scheduled to know how to use the Internet, usually after school hours or after Quran recital (diniyah) with the rule that the children can use the Internet only until magrib time (twilight).

Internet wireless installed in village meeting hall is only to support village activities, but in reality, the locals still try to use the access for free just for entertainment, especially children in the afternoon or evening. Wireless Internet installed at schools are only restricted to teachers for school activities, while students do not have access since no computer labs were available in two public schools in Gubuk Klakah. Wi-Fi spots installed at homes are usually used commercially. In addition, Wi-Fi is also installed in most homestays as part of services for visiting guests.

\section{Sustainable Livelihoods Approach In Gubugklakah Village}

In terms of influence given by human capital, not all people in the community have smooth access to the Internet due to limited data plan and access speed. Only wealthy people may have unlimited Internet access, but not those with low economic income whose access is limited to unreliable national data plan provider on their smartphone. Such different ways of Internet access, however, do not distinguish content accessed by the community.

Information technology training was once held by Telecenter in early time when it was first established. This training was aimed for village administrative staff with the hope that it can help them manage their village more efficiently and appropriately. However, there was no follow-up of this program since the staff were deemed to have 


\section{Gustomy, Damayanti, Bachtiar: "The Use of ICT For Poverty Alleviation In Gubugklakah Village, Malang Regency"}

understood the basic operation of information technology and they continued to learn on their own. The job was around administrative work such as letter and report writing. They are required to send financial report to SISKEUDES (village financial system). This demanding condition indicates that the members of the community have to learn information technology either independently or with the help of others, one way or another.

Information technology is not yet given in a school curriculum although it is essential to help students get more ready to face competition in the future. This situation may force information technology to be given by informal tuition. Along with this situation, school assignment given by teachers often force students to use Internet access for help. This forcing condition indicates that learning activities have extended from textbook to Internet for wider knowledge.

In terms of natural capital, the role of the Internet is believed to be influential. Apart from the uncertainty of local tourism management in general, tourism in Gubuk Klakah has utilised digital media such as Facebook, Instagram, website, and whatsApp to help promote the local tourism. Although the village government does not manage the tourism asset of its area, but LADESTA is always eager to promote tourism.

In addition to ecotourism, promoting the tourism potential in Gubug Klakah village also involves apple picking and milking as part of attraction in agro tourism organised by LADESTA with the help of digital media. LADESTA plays an important role in promoting tourism in Gubuk Klakah and its surrounding, and its urgency even seems to transcend that of the village government. Established by the village government of Gubuk Klakah, LADESTA is not structurally bound to the village government, as LADESTA is independently organised and it has its own basecamp. The office of LADESTA is where Telecenter in Gubug Klakah is operated, where the staff in charge of operation are also members of LADESTA. This responsibility allows LADESTA to serve as spearhead in the promotion of rural tourism through digital media. In terms of financial capital, generally the financial management of Gubug Klakah village is based on village financial system. This is an online based system and is directly connected to higher government level (the government of the regency Malang). Village secretary usually searches for insight from the Internet by seeing and observing good programs run by other villages and those programs inspire Gubug Klakah to implement similar programs. With ICT, Internet access and training given by Telecenter, according to an informant from the village, have shown a change where things seem to shift from conventional to digital. It also holds true for financial report and budgeting. Moreover, Village administrative staff that are now capable of accessing and utilising ICT and the 
Internet can get information from the government quickly and effectively. However, several staff have limited capacity to operate PC and online system.

In terms of social capital, Internet access and infrastructure of ICT (smartphone) are really helpful for people to hold a communication with their family members and other members of village community. Distance is no longer a barrier for them to communicate with others. All informants in Gubug Klakah agree that WhatsApp has been an efficient application and it is easy to operate. This application is often used to communicate with their close family members whom are referred to as 'keluarga parek' in local term, consisting of a son/daughter, a wife, parents, and other close family members. Apart from batih family and big family, the utilisation of WhatsApp is also obvious among village activities in Gubug Klakah. WhatsApp groups are getting more popular in the community. For example, activities in Neighbour Association are also communicated in the group, so are other committees and village activities; activities to celebrate Independent Day in Augusts and sedekah desa (a village ceremony held to thank God for what He has given) also utilise whatsapp group to allow the committee in charge to communicate with others. Religious events in the village also require the Internet access and the application to help them establish communication with others and it is aimed to attract more people to take part in the activities in mosque.

However, Internet does not exist without its negative impacts according to some informants. Online communication holds back people at home from any real interaction. There is also tendency of being too much devoted to phone screen. This technology has even created barriers among people to establish real social connection, dragging them further away from society. This is obvious in the situation where children's attention is absorbed to online games on the screen, not aware there are real people in their surrounding they can chat with. Another drawback is misinterpreting text messages where some get offended. This misinterpretation may extend to conflict. Online media also means wider access for hoax, like what has been sent through whatsApp groups although some informants admit they are aware of selecting genuine information of the messages.

Regarding physical capital, the existence of ICT and Internet for people and farmers of Gubug Klakah has given positive impacts to agricultural development, either in terms of promotion/sale or cultivation/agricultural techniques. Gapoktan Bumi Asri, an association for farmers of Gubug Klakah, works together with LADESTA in selling agricultural produce through holiday package and promotion/digital marketing in social media, involving the tourism of apple picking and vegetable harvesting. The marketing promotion was performed by utilising digital media and it is seen to have helped expand sales of agricultural commodity in Gubug Klakah. 


\section{Gustomy, Damayanti, Bachtiar: "The Use of ICT For Poverty Alleviation In Gubugklakah Village, Malang Regency"}

However, the utilisation of the Internet is still only around marketing the tourism, and it is not yet used to expand the commodity outside the region in a massive scale. The Internet is still used to help with the communication between farmers and collectors, not to help with commodity branding.

\section{Challenges Of ICT To Face In Village}

Although the development of Telecenter and Internet access have reached Gubug Klakah village, poverty sill seems to be an endless issue. There are 172 family heads out of 962 categorised as poor families. Poverty alleviation is facing problem since there is only minimum capacity to improve welfare of the local especially due to rarity of information and communication access, both of which should play an essential role since they are influential to both government and people. With this rarity, the government has a difficulty finding the right way to tackle poverty. Such a rarity not only affect the government, but also the local people where they have issues understanding problems they are facing and finding the solution to the problem. This also impedes the critical reflection of the people towards the existing reality. Thus, this problem slows down efforts to alleviate poverty and isolates them in the poverty circle.

This research finding seems interesting to observe further to find out to what extent the influence of the utilisation of ICT is on poverty alleviation in Gubug Klakah village. It is expected that proper strategies and policies can be made to alleviate poverty in the village.

\section{Conclusion}

The implementation of convergence of ICT in Gubug Klakah village is not optimal due to local political interest and infrastructure and human resource issues. The political interest in the utilisation of ICT facilities such as Telecenter gives a sense that the Telecenter is not more than just a formality. In tourism and agricultural sectors, ICT is utilised to help people in Gubug Klakah with promotion through digital media such as Facebook, Instagram, Website, and WhatsApp.

Village money management also utilises village financial management system that is operated online and is directly connected to the government of higher level (the government of the Regency of Malang), but ICT is still not involved in terms of financial transparency, where the transparency is still managed through conventional way by installing banners in village project areas and by informing the Neighbour Association to disseminate later. In terms of social capital, ICT is significantly influential in giving easier way to communicate with others in Gubug Klakah. The WhatsApp application is the most 
efficient, popular, and easy-to-use communication app for the community of Gubug Klakah.

\section{References}

Bappenas (n.d.). Teknologi Informasi dan Komunikasi: Strategi Peduli Kemiskinan. Accessed from https:/www.bappenas.go.id/id/data-dan-informasi-utama/isulintas-bidang/isu-lintas-bidang/penanggulangan-kemisikinan/teknologiinformasi-dan-komunikasi-strategi-peduli-kemiskinan/ 05 July 2019

Cecchini, S., and Scott, C. (2003). Can information and communications technology applications contribute to poverty reduction? Lessons from rural India. Information Technology for Development, 10(2), 73-84.

Chambers, R. (1987). Sustainable livelihoods, environment and development: putting poor rural people first.

Chapman, R., \& Slaymaker, T. (2002). ICTs and Rural Development: Review of the Literature, Current. London: Overseas Development Institute.

Chapman, R., Slaymaker, T., \& Young, J. (2003). Livelihoods Approaches to Information And Communication In Support Of Rural Poverty Elimination And Food Security. London: Overseas Development Institute.

Gubugklakah.com. (2018) Profil Desa Wisata Gubugklakah. Accessed from https://www.gubugklakah.com/; 20 March 2019

Heeks, R. (2010). Do Information and Communication Technologies (ICTs) Contribute to Development?. Journal of International Development, 22(5), 625-640.

Heeks, R., and Molla, A. (2009). Impact assessment of ICT-for-development projects: A compendium of approaches. Development Informatics Working Paper, 36.

Humas Surabaya (Public Relation of Surabaya) (2018). Pelopori e-Government, Pemkot Surabaya Sudah Ciptakan Ratusan Aplikasi. Accessed from https://humas.surabaya.go.id/2018/04/05/pelopori-e-government-pemkotsurabaya-sudah-ciptakan-ratusan-aplikasi/; 05 July 2019

Kenny, C. (2003). The Internet and Economic Growth In Less-Developed Countries: A Case Of Managing Expectations?. Oxford Development Studies, 31(1), 99-113.

Kitchin, R. (2014). The Real-Time City? Big Data and Smart Urbanism. GeoJournal, 79(1), 1-14.

Kuncoro, M. (1997). Ekonomi Pembangunan: Teori, Masalah, dan Kebijakan. Unit Penerbit Dan Percetakan PN.

Law of The Republic of Indonesia, Number 14 Year 2008 
Gustomy, Damayanti, Bachtiar: "The Use of ICT For Poverty Alleviation In

Gubugklakah Village, Malang Regency"

Law of The Republic of Indonesia, Number 25 Year 2009

Moeljarto, (1995). Politik Pembanguan Sebuah Analisis Konsep, Arah dan Strategi, PT. Tiara Wacana:Yogyakarta.

Soejatmiko (ed.). (2018) Geliat Homestay di Gubugklakah dan Ngadas, Gairahkan Wisata Bromo Rute Malang. JawaPos (online). Accessed from https://www.jawapos.com/entertainment/travelling/02/03/2017/geliat-homestaydi-gubugklakah-dan-ngadas-gairahkan-wisata-bromo-rute-malang; 20 March 2019

Soriano, C. R. R. (2007). Exploring The ICT And Rural Poverty Reduction Link: Community Telecenters And Rural Livelihoods In Wu'an, China. The Electronic Journal of Information Systems in Developing Countries, 32(1), 1-15.

Suyanto, B. and Sutinah. (2010). Metode Penelitian Sosial. Jakarta: Kencana.

Tambo, I. (2003). ICT and Economic Growth in Developing Countries.

Tempo.co. (2018) Kabupaten Malang Promosikan 13 Desa Wisata. Accessed from https://travel.tempo.co/read/572767/kabupaten-malang-promosikan-13-desawisata; 20 March 2019

UNDP (1990) Human Development Report 1990. New York; Oxford University Press

UNDP (2001). Role of UNDP in Information and Communication Technology for Development. Annual Session 2001. New York. 